\title{
Napoved pojava pooglenitve bukve v Sloveniji 2014
}

\section{Nikica OGRIS*}

\section{Uvod}

Pooglenitev bukve je bolezen navadne bukve ( $F a-$ gus sylvatica L.), ki jo povzroča novčičasta biskonjoja, Biscogniauxia nummularia (Bull.) Kuntze (Fungi : Ascomycota : Sordariomycetes : Xylariales). B. nummularia je $\mathrm{v}$ običajnih razmerah neškodljiv endofit skorje, postane pa parazit, ko se pojavijo ustrezni pogoji: $2-3{ }^{\circ} \mathrm{C}$ višje povprečne mesečne temperature in daljša sušna obdobja (vsaj 6 mesecev manj kot $50 \%$ padavin $\mathrm{v}$ primerjavi s 30 letnim povprečjem) ali pa samo višje temperature $4-5{ }^{\circ} \mathrm{C}$ (lahko je dovolj padavin) (Hendry in sod., 1998). Novčičasta biskonjoja po sušnem stresu povzroči odmiranje predelov skorje $\mathrm{v}$ obliki klinov ali pasov kjerkoli na deblu (slika 1). Odmrli deli skorje se kasneje luščijo in odpadajo. Trosnjaki $B$. nummularia se razvijejo na odmrli skorji iz prejšnjega leta. Mladi trosnjaki so prekriti z opnastim odpadljivim slojem, ko ta odpade, se sprosti črna površina strome v obliki krogov (novčičev) velikosti 5-20 mm (slika 2). Če je odmrl velik pas skorje, ki ga kalus ne more dovolj hitro zarasti, $v$ drevo prodrejo glive, ki povzročajo trohnobo, in zato okuženo drevo hitro zgublja tehnično vrednost. Če poškodba zajame večji del debla, se drevo lahko posuši (Ogris, 2014).

V Sloveniji imamo zabeležene vsaj tri dogodke, kjer je B. nummularia povzročila veliko površinsko odmiranje navadne bukve: v Prekmurju v bližini Lendave po letu 2003 (Jurc, 2007), na Primorskem na Brkinih po letu 2003 (Jurc in sod., 2007), na območju Bohorja po letu 2005 (Ogris in Jurc, 2008).

Endofitni način življenja $B$. nummularia omogoča hiter razvoj in izrazito patogenost za navadno bukev v sušnem ali drugem stresnem okolju (Granata in Sidoti, 2004; Nugent in sod., 2005). Gliva B. nummularia se hitreje razvija v drevesu ob višjih temperaturah, tj. 25$30{ }^{\circ} \mathrm{C}$ in nad $30{ }^{\circ} \mathrm{C}$, kjer zlahka tekmuje z drugimi glivami (Hendry in sod., 2002), kar jo naredi nevarnejšo $\mathrm{v}$ kontekstu podnebnih sprememb (Lonsdale in Gibbs, 1996; La Porta in sod., 2008).

Slovenijo je v letu 2013 prizadela huda poletna suša. Vroče in suho vreme se je začelo v mesecu juniju in se je nadaljevalo v julij in avgust (Cegnar, 2013a, 2013 b , 2013c). Zato v letu 2013 pričakujemo povišano stopnjo intenzitete poškodb zaradi pooglenitve bukve. Cilj raziskave je bil izdelati kratkoročno napoved potencialne pojavitve poškodb zaradi $B$. nummularia na navadni bukvi v Sloveniji v letu 2014.

\section{Metode dela}

Kratkoročno napoved pojavitve pooglenitve bukve za 2014 smo izvedli na podlagi izboljšanega empiričnega modela, ki smo ga razvili za namen izdaje napovedi za 2013 (Ogris, 2013). Model upošteva korelacijo pojavljanja pooglenitve bukve in klimatskih parame- trov (Hendry in sod., 1998). Empirični model je bil zgrajen iz naslednjih dveh pravil:

- pooglenitev bukve se potencialno pojavi, ko je povprečna maksimalna mesečna temperatura višja za $2,5^{\circ} \mathrm{C}$ ali več in ob daljših sušnih obdobjih, tj. vsaj v 4 mesecih pade manj kot $50 \%$ padavin v primerjavi s 30 letnim povprečjem;

- pooglenitev bukve se potencialno pojavi, ko so povprečne maksimalne mesečne temperature višje za $4{ }^{\circ} \mathrm{C}$ ali več v primerjavi s 30 letnim povprečjem, kjer količina padavin ni upoštevana.

Ker je B. nummularia termofilni patogen, smo pri izračunu razlike med povprečno maksimalno mesečno temperaturo v letu 2013 in povprečno maksimalno mesečno temperaturo v obdobju 1971-2000 upoštevali samo mesece in območja s povprečno maksimalno mesečno temperaturo nad $28,9^{\circ} \mathrm{C}$. Omenjeni temperaturni prag smo določili glede na podatek, da pooglenitev bukve pred letom 2003 ni povzročala primarnih poškodb navadne bukve v Sloveniji; zato smo za temperaturni prag vzeli najvišjo povprečno maksimalno temperaturo najtoplejšega meseca, tj. julija $\mathrm{v}$ obdobju 1971-2000. Izbrani prag je ena izmed izboljšav modela. Poleg tega smo namesto povprečne mesečne temperature upoštevali povprečno maksimalno mesečno temperaturo.

Zbrali smo podatke o povprečni maksimalni mesečni temperaturi in skupni količini padavin po mesecih za 34 meteoroloških in klimatoloških postaj ter 151 padavinskih postaj. Pridobili smo podatke od januarja do decembra za leto 2013 (ARSO, 2014). Za primerjalno referenčno obdobje smo vzeli 1971-2000 (ARSO, 2006a, 2006b).

Glavna pomanjkljivost izvornega modela iz leta 2013 je bila njegova prostorska ločljivost napovedi, saj se je nanašala samo na točkovne lokacije, tj. na lokacije meteoroloških postaj. V tej raziskavi smo model izboljšali tako, da smo uporabili statistično metodo prostorske interpolacije kokriging (Chilčs in Delfiner, 2008), s katero smo pridobili karte povprečne maksimalne mesečne temperature in skupno količino padavin po mesecih v ločljivosti $1 \mathrm{~km} \times 1 \mathrm{~km}$. Za spremenljivko zunanjega vpliva smo izbrali digitalni model reliefa $\mathrm{v}$ ločljivosti $100 \mathrm{~m} \times 100 \mathrm{~m}$ (GURS, 2000). Karte smo izdelali $\mathrm{v}$ programski opremi ESRI ArcGIS $10.2 \mathrm{z}$ orodjem za izdelavo geostatističnih in prostorskih analiz. Validacijo smo izvedli z navzkrižnim preverjanjem (angl. crossvalidation). Modeli kokriginga so dostopni pri avtorju.

Končni rezultat modela je karta verjetnosti pojava pooglenitve bukve v Sloveniji v 2014, ki smo jo izračunali po naslednji enačbi:

$$
\mathrm{v}=\left(\mathrm{a}+\mathrm{T}_{4} \times \max [\mathrm{a}] / \max \left[\mathrm{T}_{4}\right]\right) /\left(\max \left[\mathrm{T}_{2,5}\right] \times 50\right.
$$

$\left.\times \max \left[\mathrm{P}_{\mathrm{st}}\right]+\max [\mathrm{a}]\right)$, 
kjer a $=\mathrm{T}_{2,5} \times(100-\mathrm{P}) \times \mathrm{P}_{\mathrm{st}}, \mathrm{T}_{2,5}=\left|\mathrm{T}_{\mathrm{i}}-\mathrm{rT}_{\mathrm{i}}\right| \geq 2,5$ ${ }^{\circ} \mathrm{C}$ in $\mathrm{T}_{\mathrm{i}}>28,9{ }^{\circ} \mathrm{C}, \mathrm{T}_{\mathrm{i}}=$ povprečna mesečna maksimalna temperatura $\mathrm{v}$ mesecu $\mathrm{i}, \mathrm{rT}_{\mathrm{i}}=$ referenčna povprečna mesečna maksimalna temperatura $\mathrm{v}$ mesecu i za obdobje 1971-2000, $\mathrm{P}=\mathrm{P}_{\mathrm{i}} / \mathrm{rP}_{\mathrm{i}} * 100$, ko je $\mathrm{P}_{\mathrm{i}} / \mathrm{rP}_{\mathrm{i}} * 100<$ $50, \mathrm{P}_{\mathrm{i}}=$ skupna količina padavin $\mathrm{v}$ mesecu $\mathrm{i}(\mathrm{mm}), \mathrm{rP}_{\mathrm{i}}$ referenčna povprečna skupna količina padavin $\mathrm{v}$ mesecu i (mm) v obdobju 1971-2000, $\mathrm{P}_{\text {st }}=$ število mesecev, ko je padlo manj kot $50 \%$ padavin $\mathrm{v}$ primerjavi $\mathrm{z}$ 1971-2000, $\mathrm{T}_{4}=\left|\mathrm{T}_{\mathrm{i}}-\mathrm{r} \mathrm{T}_{\mathrm{i}}\right| \geq 4{ }^{\circ} \mathrm{C}$ in $\mathrm{T}_{\mathrm{i}}>28,9{ }^{\circ} \mathrm{C}, \max [\mathrm{y}]$ $=$ maksimum izbrane spremenljivke.

Model verjetnosti pojava pooglenitve bukve ima razpon vrednosti med 0 in 1 , kjer 0 pomeni najmanjšo in 1 največjo verjetnost pojava bolezni. Ogrožene površine smo korigirali tako, da smo upoštevali samo površine, kjer je prisotna bukev, tj. na približno 346.648 ha (ZGS, 2012).

\section{Rezultati}

Natančnost modela definirata dve spremenljivki, tj. skupna mesečna količina padavin in povprečna maksimalna mesečna temperatura, ki smo jo pridobili s pomočjo kokriginga. Povprečna standardna napaka za povprečno maksimalno mesečno temperaturo je znašala $0,3{ }^{\circ} \mathrm{C}$ in za mesečno količino padavin $16 \mathrm{~mm}$.

$\mathrm{V}$ letu 2013 je primanjkovalo padavin po vsej Sloveniji (slika 3). Največ padavin v posameznem mesecu je primanjkovalo (padlo je samo 10,3-20\% običajnih padavin) v severovzhodnem delu države, na Primorski ter na območju okrog Mokronoga in Grosupljega. Pomemben dejavnik za pojavitev pooglenitve bukve je primanjkovanje padavin skozi daljši čas, tj. vsaj štiri mesece (slika 4). Območja, kjer je vsaj štiri mesece padlo manj kot $50 \%$ padavin v primerjavi s povprečjem 1971-2000, obsegajo 35,3 \% Slovenije. Na območju Pohorja med Roglo, Lovrencem in Rušami je kar 6 mesecev primanjkovalo padavin. Šest mesecev je primanjkovalo padavin tudi na manjšem območju pri Sviščakih pod Velikim Snežnikom. Vsaj štiri mesece je padlo manj kot $50 \%$ padavin na širšem območju vzhodne Slovenije, Notranjske, Kočevskega, pa tudi na manjših območjih Julijskih in Kamniško - Savinjskih Alp.

Spremembo povprečne maksimalne mesečne temperature za $2,5^{\circ} \mathrm{C}$ ali več smo zaznali na $35,6 \%$ države in je zaobsegla predvsem vzhodni del Slovenije, Celjsko kotlino, Novo meško - Krško - Brežiško kotlino, Ljubljansko kotlino, Belo krajino, dolino Kolpe, priobalno območje, Soško dolino, dolino reke Idrijce (slika 5). Posebej veliki odkloni $\left(\geq 4{ }^{\circ} \mathrm{C}\right)$ povprečne maksimalne mesečne temperature so zajeli $2,5 \%$ Slovenije, tj. Goričko, predel med Ljutomerom in Ormožem, območje med Mariborom in Šentiljem, posamezni predeli $\mathrm{v}$ dolini Drave, Save in Idrijce, posamezna območja Haloz, Kozjanskega, Posavskega hribovja, Gorjancev, Suhe krajine in Bele krajine.

Pooglenitev bukve se lahko potencialno pojavi na 13,3 \% (46.045 ha) površin bukovih gozdov (slika 6, preglednica 1). Najbolj ogroženi sta gozdnogospodarski območji (GGO) Brežice $(27,6$ \% vse ogrožene površine) in Maribor (26,3\%). Večji delež potencialno ogroženih površin se nahaja še v GGO Novo mesto $(18,3 \%)$, Celje (17\%), Murska Sobota $(5,9 \%)$, Lju- bljana $(2,9 \%)$ in Tolmin $(1,8 \%)$. Zelo visoka verjetnost $(\mathrm{v} \geq 0,8)$ pojava bolezni je na $7,1 \%$ (3.270 ha) vseh potencialno ogroženih površin. Posebej je izpostavljeno zahodno Goričko, posamezne površine pri Šentilju v Slovenskih goricah, posamezni predeli ob reki Dravi od Radelj do Ptuja, Haloze, Kozjansko, posamezna območja ob reki Savi od Zagorja do Sevnice, Gorjancev, Bele krajine, Suhe krajine in Krima. Na večini ogroženih območij $(75,3 \%)$ je verjetnost pojava bolezni majhna $(\mathrm{v}<0,4)$. Srednja in visoka verjetnost $(0,4<=\mathrm{v}<0,8)$ pojava pooglenitve bukve obsega 17,6 $\%$ vseh potencialno ogroženih površin in se nahajajo $\mathrm{v}$ neposredni bližini območij z zelo veliko ogroženostjo, tj. obsegajo Goričko, območje med Mariborom in Šentiljem, območje med Mariborom, Slovenske Bistrice in Miklavžem na Dravskem polju, območje severno od Ptuja, predel med Ljutomerom in Ormožem, osrednji del Haloz, območja v dolini Idrijce, Nadiže, Save med Litijo in Zidanim mostom ter Savinje med Laškim in Zidanim mostom.

\section{Razprava}

Rezultati modela nam lahko v določeni meri pomagajo pri spremljanju pojava pooglenitve bukve v letu 2014, saj nam pokažejo, na katera širša območja v Sloveniji se naj osredotočimo pri iskanju poškodb zaradi novčičaste biskonjoje.

Zanesljivost modela bi lahko bila večja, če bi v njegova pravila vključili tudi lastnosti tal, kot so vodna kapaciteta, prepustnost in talni tip, ki zelo vplivajo na pojavitev sušnega stresa pri navadni bukvi. Napovedno točnost modela bi lahko konec leta 2014 preverili s pomočjo podatkov s terena, kjer se bo bolezen dejansko pojavila.

Podobne lastnosti kot B. nummularia ima Biscogniauxia mediterranea (De Not.) Kuntze, ki se prav tako pojavlja kot fakultativni parazit skorje ob sušnem stresu in višjih temperaturah na ceru (Quercus cerris L.) in puhastem hrastu (Quercus pubescens Willd.), kjer povzroča bolezen, ki jo imenujemo pooglenitev hrastov. V Sloveniji se je pojavila po letu 2003 v jugozahodnem delu Slovenije (Jurc in Ogris, 2004). Obstaja verjetnost, da bo pooglenitev bukve spremljala tudi pooglenitev hrastov v 2014 zaradi sušnega in vročega poletja v 2013.

\section{Zahvala}

Prispevek je nastal v okviru Javne gozdarske službe, naloge Poročevalsko, prognostično-diagnostične službe za gozdove, ki se izvaja na Gozdarskem inštitutu Slovenije in jo financira Ministrstvo za kmetijstvo in okolje.

\section{Viri}

ARSO. 2006a. Povprečna maksimalna temperatura zraka za obdobje 1971-2000: 12 mesečnih kart in 1 letna karta v digitalni rasterski obliki z ločljivostjo $1 \mathrm{~km}$. Ljubljana, Agencija Republike Slovenije za okolje, Urad za meteorologijo

ARSO. 2006b. Povprečna mesečna in letna vsota korigiranih padavin za obdobje 1971-2000: 12 mesečnih kart in 1 letna karta v digitalni rasterski obliki z ločljivostjo $1 \mathrm{~km}$. Ljubljana, Agencija Republike Slovenije za okolje, Urad za meteorologijo

ARSO. 2014. Arhiv - opazovani in merjeni meteorološki podatki po Sloveniji. http://meteo.arso.gov.si/met/sl/app/webmet (11. 4. 2014) 
Cegnar T. 2013a. Podnebne razmere v avgustu 2013. Naše okolje, 20, 8: 3-24.

Cegnar T. 2013b. Podnebne razmere v juliju 2013. Naše okolje, 20, 7: 3-24.

Cegnar T. 2013c. Podnebne razmere v juniju 2013. Naše okolje, 20, 6: 3-23.

Chilès J.-P., Delfiner P. 2008. Geostatistics: modeling spatial uncertainty. John Wiley \& Sons, Inc.: 695 str.

Granata G., Sidoti A. 2004. Biscogniauxia nummularia: pathogenic agent of a beech decline. Forest Pathology, 34: 363-367.

GURS. 2000. Interferometrični radarski digitalni model višin $100 \times 100$ m (InSAR DMV 100). Ljubljana, Ministrstvo za okolje in prostor, Geodetska uprava Republike Slovenije

Hendry S.J., Boddy L., Lonsdale D. 2002. Abiotic variables effect differential expression of latent infections in beech (Fagus sylvatica). New Phytologist, 155, 3: 449.

Hendry S.J., Lonsdale D., Boddy L. 1998. Strip-cankering of beech (Fagus sylvatica): Pathology and distribution of symptomatic trees. New Phytologist, 140, 3: 549-565.

Jurc D. 2007. Patogeni drevja in spremembe podnebja v Sloveniji. V: Podnebne spremembe - vpliv na gozd in gozdarstvo. Jurc M. (ur.). Ljubljana, Biotehniška fakulteta, Oddelek za gozdarstvo in obnovljive gozdne vire: $203-216$.

Jurc D., Ogris N. 2004. Sušenje cera in drugega drevja pod hribom Žekanec. Ljubljana, Gozdarski inštitut Slovenije, Poročevalska, diagnostična in prognostična služba za varstvo gozdov: 10 str.

Jurc D., Ogris N., Jurc M. 2007. Gliva novčičasta biskonjoja (Biscogniauxia nummularia) povzroča pooglenitev navadne bukve (Fagus sylvatica) na Brkinih. Ljubljana, Gozdarski inštitut Slovenije, Poročevalska, diagnostična in prognostična služba za varstvo gozdov: 14 str.

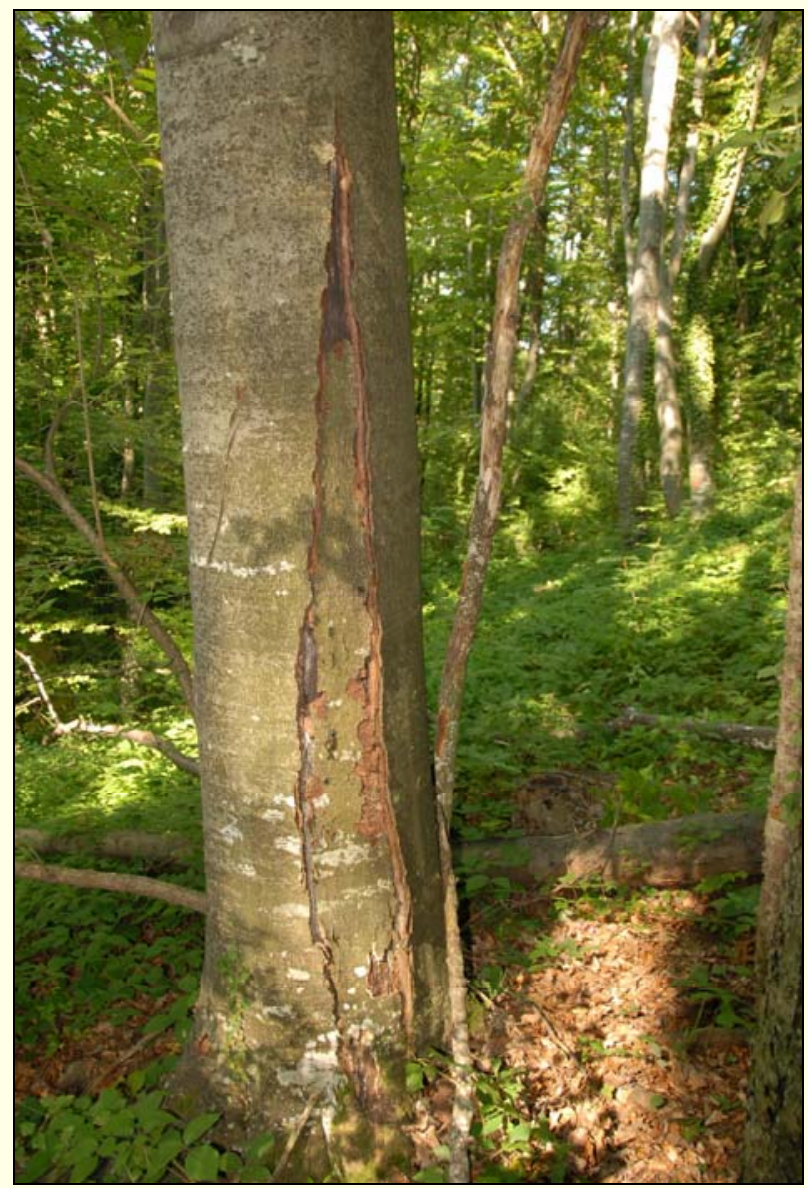

Slika 1: Nekroza in odmiranje skorje v obliki klina ali pasov, ki ga je povzročila Biscogniauxia nummularia (foto: N. Ogris)
La Porta N., Capretti P., Thomsen I.M., Kasanen R., Hietala A.M., Von Weissenberg K. 2008. Forest pathogens with higher damage potential due to climate change in Europe. Canadian Journal of Plant Pathology, 30, 2: 177-195.

Lonsdale D., Gibbs J.N. 1996. Effect of climate change on fungal diseases of trees. V: Fungi and environmental change. Symposium of the British Mycological Society, held at Cranfield University, March 1994. Frankland J.C., Magan N., Gadd G.M. (ur.). Cambridge, British Mycological Society: 1-19.

Nugent L.K., Sihanonth P., Thienhirun S., Whalley A.J.S. 2005. Biscogniauxia: a genus of latent invaders. Mycologist, 19, 1: 40-43.

Ogris N. 2013. Kratkoročna prognoza pojava pooglenitve bukve (Biscogniauxia nummularia) v Sloveniji. V: Zbornik predavanj in referatov 11. slovenskega posvetovanja o varstvu rastlin $\mathrm{z}$ mednarodno udeležbo (in okrogle mize o zmanjšanju tveganja zaradi rabe FFS v okviru projekta CropSustaIn), Bled, 5.-6. marec 2013. Trdan S., Maček J. (ur.). Ljubljana, Društvo za varstvo rastlin: 62-68.

Ogris N. 2014. Priročnik za določevanje vzrokov poškodb drevja: medmrežna različica. www.zdravgozd.si (11. 4. 2014)

Ogris N., Jurc D. 2008. Suša je omogočila nekaterim endofitom in fakultativnim parazitom povzročiti poškodbe bukve na področju Reštanja, Bohor. Ljubljana, Gozdarski inštitut Slovenije: 5 str.

ZGS. 2012. Gozdni fondi. Podatkovna zbirka. Zavod za gozdove Slovenije

*Gozdarski inštitut Slovenije, Večna pot 2, 1000 Ljubljana nikica.ogris@gozdis.si

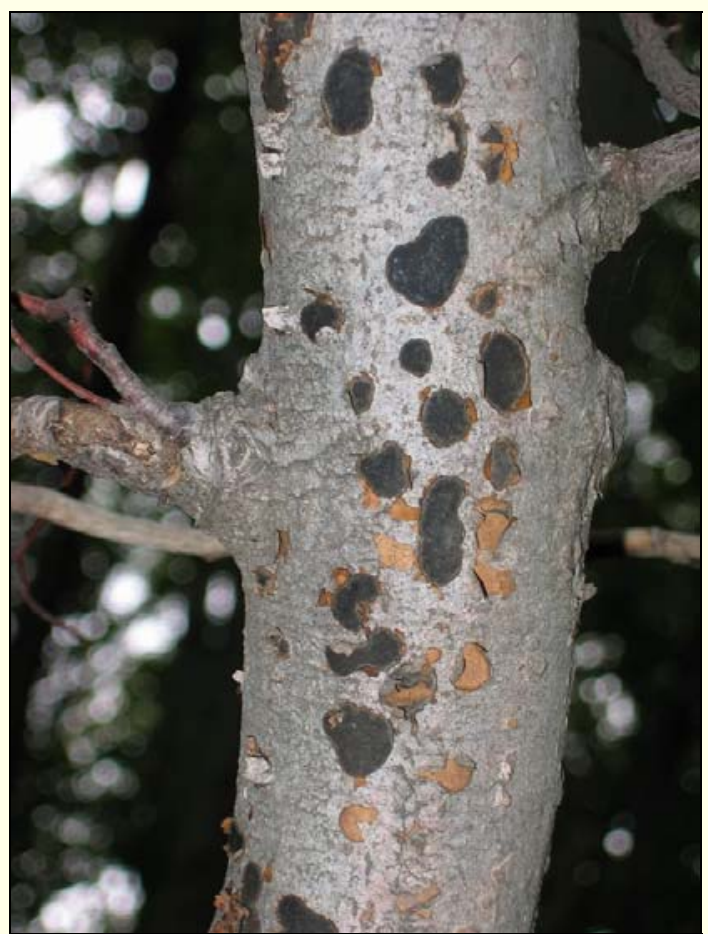

Slika 2: Trosnjaki glive Biscogniauxia nummularia (foto: $\mathrm{N}$. Ogris) 


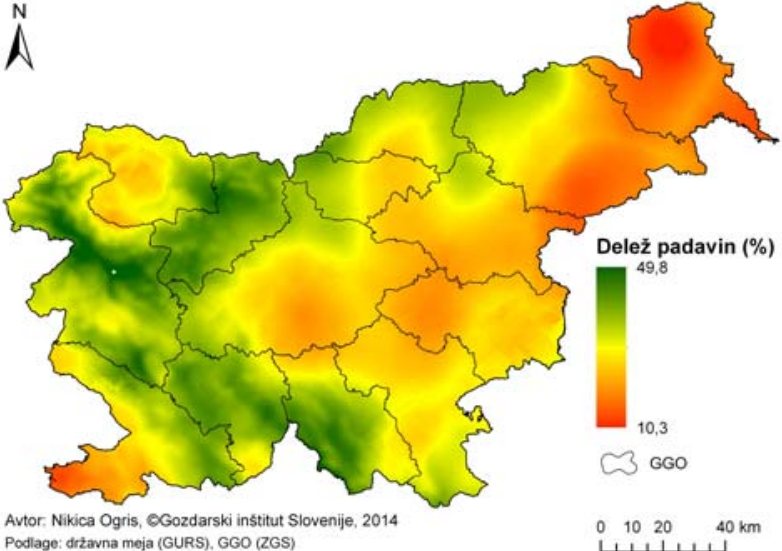

Slika 3: Višina padavin v 2013 v primerjavi s povprečjem 19702000. Prikazana so območja z manj kot 50 \% padavin.

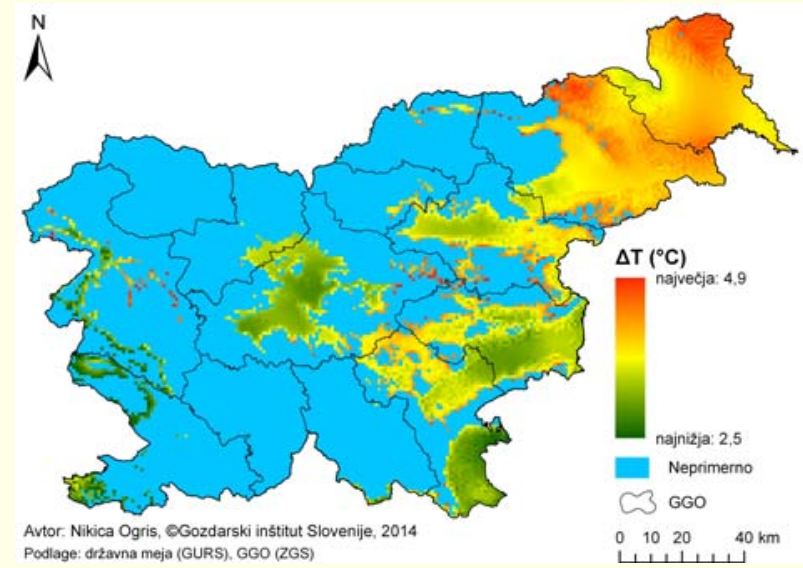

Slika 5: Sprememba povprečne maksimalne mesečne temperature v primerjavi z obdobjem $1970-2000$ večja kot $2,5^{\circ} \mathrm{C}$

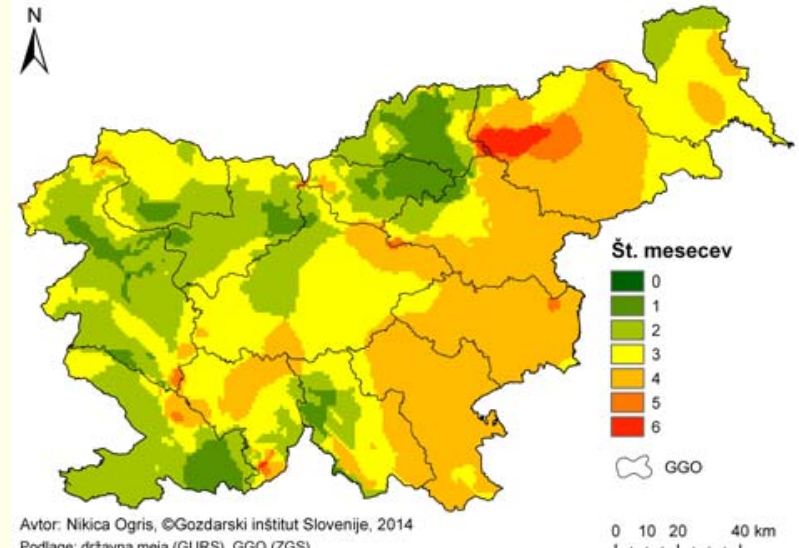

:

Slika 4: Število mesecev, ko je padlo manj kot $50 \%$ padavin v primerjavi s 30 letnim povprečjem.

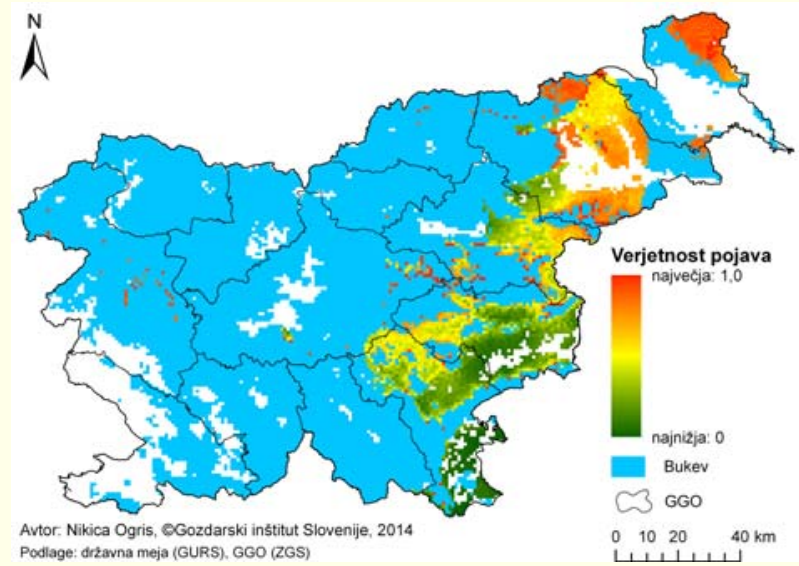

Slika 6: Verjetnost pojava pooglenitve bukve v Sloveniji v 2014

\% celotne ogrožene površine glede na verjetnost pojava

\begin{tabular}{lrrrrrr}
\hline GGO & Površina (ha) & \multicolumn{1}{c}{ vse } & majhna & \multicolumn{1}{c}{ srednja } & visoka & zelo visoka \\
BREŽICE & 12.721 & 27,6 & 25,8 & 0,5 & 0,1 & 1,2 \\
MARIBOR & 12.101 & 26,3 & 15,2 & 8,7 & 0,2 & 2,1 \\
NOVO MESTO & 8.434 & 18,3 & 17,8 & 0,0 & 0,0 & 0,5 \\
CELE & 7.842 & 17,0 & 14,6 & 0,8 & 0,0 & 1,6 \\
MURSKA SOBOTA & 2.734 & 5,9 & 0,8 & 4,6 & 0,0 & 0,5 \\
UUBLJANA & 1.317 & 2,9 & 1,0 & 0,6 & 0,0 & 1,2 \\
TOLMIN & 829 & 1,8 & 0,0 & 1,8 & 0,0 & 0,0 \\
SLOVENJ GRADEC & 38 & 0,1 & 0,0 & 0,1 & 0,0 & 0,0 \\
KOČEVJE & 27 & 0,1 & 0,0 & 0,0 & 0,0 & 0,0 \\
NAZARJE & 3 & 0,0 & 0,0 & 0,0 & 0,0 & 0,0 \\
Skupaj & 46.045 & 100,0 & 75,3 & 17,2 & 0,4 & 7,1 \\
\hline PI
\end{tabular}

Preglednica 1: Potencialno ogrožena površina po gozdnogospodarskih območij zaradi pooglenitve bukve v Sloveniji v 2014. Legenda verjetnosti pojava: majhna: $0<\mathrm{v}<0,4$; srednja: $0,4 \leq \mathrm{v}<0,6$; visoka: $0,6 \leq \mathrm{v}<0,8$; zelo visoka: $\mathrm{v} \geq 0,8$. 